\title{
INCLUSION AND EXCLUSION IN POLITICAL DISCOURSE: DEIXIS IN BARRACK OBAMA'S SPEECHES
}

\author{
Wiwik Yully Widyawati \\ Program of English Education, Faculty of Language and Art, University of Indraprasta PGRI \\ Jalan Nangka No. 58C Tanjung Barat, Jagakarsa, South Jakarta 12530 \\ wiwik121@gmail.com
}

\begin{abstract}
This study examines the use of deixis for personal, spatial, and temporal anchorage of political discourse. Using two thematically and contextually different speeches of obama as its database., the paper recognize how politicians can associate with and dissociate from actions taken by them or their officer at different time. I conclude by locating some of antics of political leaders to conscript their subjects into accepting their views on conversial issues or position.
\end{abstract}

Key word: inclusion and exclusion, political discourse, deixis

\begin{abstract}
ABSTRAK
Penelitian ini bertujuan untuk menganalisis penggunaan deiksis persona mengenai tempat, dan perlabuhan sementara dalam wacana politik. Dalam analisis ini menggunakan dua pendekatan tematis dan kontekstual dengan menggunakan pidato obama yang berbeda sebagai data, artikel ini menganalisis bagaimana politisi dapat menghubungkan dengan dan memisahkan dari tindakan yang diambil oleh mereka atau petugas mereka pada waktu yang berbeda. Saya menyimpulkan dengan menempatkan beberapa kejenakaan dari para pemimpin politik untuk mengerahkan rakyat mereka untuk menerima pandangan mereka tentang isu-isu conversial atau posisi.
\end{abstract}

Kata kunci: pencantuman dan pelepasan (pengeluaran), wacana politik, deksis 


\section{INTRODUCTION}

Language is a means of communication. Communication using language is the most universal for anyone. All people in the world have language. Language is used to realize every person's hopes, aspiration, and thinking, etc. A language is used to carry out their daily activities. They can express their idea through language both in written and spoken form. Language has an important role in human life. It is used as a means of communication in every human.

Hornby (1995:662) assumes that "Language is the system of sounds and words used by human to express their thoughts and their feelings". Language and politics are social stances; the one, a medium used by society for the purposes of communication and cohabitation, the other, loosely, the ideas and activities used for gaining and exercising power in society. As such a linguistic study of political language, that which we intend to does here, conflates the social components of the two stances. It is van Dijk's (2004:8-9) characterization of the field of politics that establishes, most succinctly, politics as discourse:

". . . this field may briefly-and some what traditionally bedefined by its overall systems

(democracy,dictatorship), special social macro actions, such as government, legislation, elections, or decision making, . . . micro practices, interactions or discourses, such as parliamentary debates, canvassing or demonstrations, . . . special social relations, such as those of institutional power, ... special norms and values (e.g. freedom, equality etc) ... political cognitions, such as political ideologies."

Politics is thus a discursive domain, not just because it situates language in action but also because the action is contextualized.

The use of linguistic parameters for interpreting political language is a fairly recent enterprise. According to Wilson (1990), Geis (1987) is the first complete textbook written by any linguist on political language. Ever since, however, linguists have devoted considerable attention to political discourse: Wilson (1990), from the point of view of linguistic pragmatics, Cap (2002) from an eclectic linguistic angle of vision, and Chilton (2004), from the discourse-analytic perspective, to mention but a few.

Language is used, sometimes, for identification purposes; for delineating positions according to" in "and "out" relations. By this is meant language serves the purpose of including its users and excluding its non-users. But it is not this wide scope of inclusion and exclusion that we would apply here. Inclusion, in this paper, conceptualizes the deictic acts of including the speaker in the political position and activities being presented, and exclusion, at the other end, distances the speaker from such political ideas and activities. Our "inclusion" and "exclusion" are therefore akin to Miller's (2004) bifurcation of "alignment" and "alienation".

Barack Hussein Obama born August 4, 1961 is the $44^{\text {th }}$ and current President of the United States. He is the first African American to hold the office. Obama previously served as a United States Senator from Illinois, from January 2005 until he resigned after his election to the presidency in November 2008. He has ever do speech before he become president that he will 
end iran war. Obama won the election and sworn in the front of citizen on January, 20, 2009. When he become president on that date, he did speech. His speeches are something the people want and it is hoped by his citizen. It also something well though -out, imbued with political experience, and therefore very useful for the analysis of political language.

Two of Obama's speeches have been chosen for explication of the inclusion -exclusion paradigm. The first, the inclusive text $A$, is Obama's Speech when he became the first black president America in the year 2009 entitle 'Obama Inaugural Address'. In the speech, president of Obama present the problem of the country like the crisis and there is the war of the world during the government of bush and he get the task to continue Bush' government to overcome the problems of his country because he is a new president. In this speech, Obama also present about the greatness the God is the best. Barrack Obama speak as president that he will run his government and promise for his citizen. Text $\mathrm{B}$, the exclusive, is the transcribed Speech of Obama is declaration "literacy and education in A $21^{\text {st }}$ Century economy on June $25^{\text {th }} 2005$. In this text, the speaker tells the importance of library and economy and injustice of the DPR's treatment.

Presidential speeches have been subjected to linguistic inquiries for some time now. This focus is probably due to the institutional voices which these speeches project: presidents are considered the "most eligible" representatives of their countries, whose words therefore bear the semantic load of their nation's ethos and soul.

The literature is replete with investigations of presidential rhetoric, often from not-too-clearly demarcated, heterogeneous perspectives. One way of categorizing these works is according to their essential linguistic bases. In this direction, we have had linguistic enquiries of presidential speeches from the pragmatics standpoint (see Adetunji, 2005; Ayodabo, 2003; Cap, 2002; Chilton and Schaffner, 1997; Rudd, 2004; Yusuf, 2003), from the discourseanalytic angle of vision (see Miller, 2004; Teittinen, 2000), and from the stylistics position (see Adegoju, 2005; Oha,1994). Presidential speeches may also be delineated into thematic preoccupations. As such we have studies on inaugural address (Adetunji, 2005; Cap, 2002), address to Party Congress (Chilton and Schaffner, 1997), positive projection of government's position for her people's endorsement (Miller, 2004; Rudd, 2004; Teittinen, 2000), situated conflict rhetoric (Adegoju, 2005; Oha, 1994) ,and "negative other presentation" (Ayodabo, 2003; Yusuf, 2003 ). In this present research, the writer wants to analyze the deixis in this text, what kind of deixis including in political discourse.

Deixis is reference by means an expression whose interpretation is relative to the (usually) extralinguistic context of the utterance, such as: who is speaking, the time or place of speaking, the gestures of the speaker, or the current location in the discourse. Here are examples of deictic expression s: I, you, now, there, that, the following, tenses. "Deixis also belongs within the domain of pragmatics because it directly concerns the relationship between the structure of language and the contexts in which they are used" (Levinson, 1983:55).

The quotation above is unambiguous locating deixis as an aspect of meaning in use in context. Also called "indexicals" or "indexical 
expressions", deictics (deixis' indicative elements) are linguistic pointers which orientate reference in an utterance to "the contextual coordinates of the utterance" (Mey, 2001:54). The situation of deixis therefore presupposes a speaker who provides meaning for an utterance, and expects the audience to interpret the utterance's meaning from the speaker's viewpoint.

Deictics are of three traditional categories; personal, spatial, temporal. According to Trask (1999:68), personal deictic “. . . allows distinctions among the speaker, the addressee, and everyone else". Odebunmi and Olaniyan (2005:7) conceptualize this type of deictic, more succinctly:

"It is realized through personal pronouns in several contexts of use. The first person pronoun includes the speaker,, the second person includes the addressee, but the third person excludes both the speaker and the addressee. So such pronouns as I, we, you, he/she, it (referential, not pleonastic) and their variants (e.g my, mine, your, their, its) are personal deictics."

However, the references indicated by this type of indexicals may not be as obviously demarcated as they seem. From a particular angle, Thomas (1995:10) submits:

"Even without any remove of time or place, it can be difficult to assign reference correctly to any utterance containing a third person pronoun (he, she, it, they) since these have an almost infinite number of possible referents."

Thus it is from the speaker's perspective or point of view that we would understand best the referents of the personal indexicals which the speaker employs. The speaker is thus the deictic centre of an utterance. (Mey, 2000, 2001; Odebunmi and Olaniyan, 2005), whose "properties" are contextually encoded and variably indicated (Kataoka, 2004). Kataoka (2004:412), citing Volosinov (1973) and Goffman (1981) expatiates on the complex indeterminacy of the singular, firstperson deictic, "I":

"The speakership, usually achieved by the first-person pronoun "I", is essentially multi-vocal . . and is a reflection of multiple personae, diverting into (at least) several discursive stances realized as, for example, the animator (utterer), the author (composer), and/or the principal (responsible party) . . - as well as the hearership variably conceived of as, say, addressee, ratified hearer, bystander, eavesdropper etc. .."

As such, even "I" whose reference should be easily accessible, really shifts according to both the context of utterance and the speaker's intention. Rees (1983:16) developed a pronominal scaling which directed attention to the referential capability of political language:

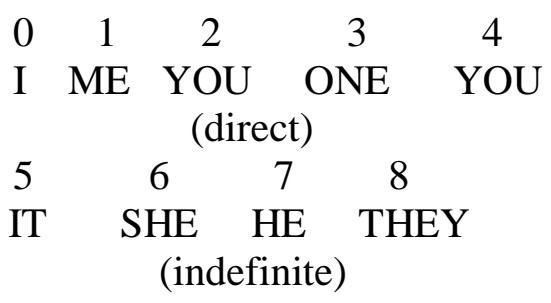

Starting from the deictic centre "I" to the distant other, "they", the scale shows the movement from the proximal to the distal in the use of pronominals for political referencing. Maitland (1988:82), while expanding Rees (1983), the generic conceptualisation of 
pronominal use, claiming that two individual speakers could, for different reasons, deploy different personal deictics for self-distancing:

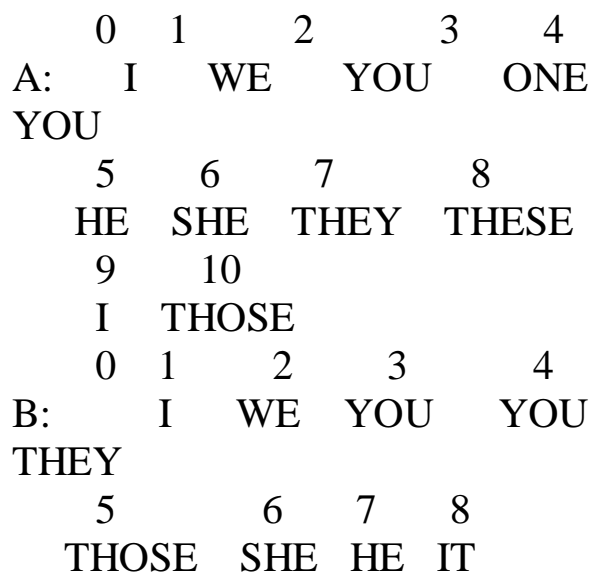

The distinction, between the two scales above, dependent on the speaker's perception of the use of personal indexical, is captured by Wilson (1990:59):

". . . for example, if the speaker perceives 'those' as more negative than 'it', with 'those' associated with facelessness, and 'it' being treated as a 'neutral' term, then 'those' will be placed further away from 'I'. on the other hand, if 'it' is perceived as sub-human, with 'those' being perceived simply as not present, then, in this case, it may be placed further away from the 'I'."

As such, it is the speaker's intention and attitude to the topic of discussion and the context of discourse that condition his/her use of indexicals.

Spatial deictics, deictics of place, "do not mean much in isolation, it is only when you know where the speaker is standing or what the speaker is indicating that they become truly meaningful" (Thomas, 1995:9). These indexical, indicated by demonstratives (e.g this, those) and place adverbials (e.g here, there) are used by the speaker to locate their referents either as being near/proximal (here, this) or far/distal (those, there) Many pragmaticians, including Braun (2001); Odebunmi (2001), and Yule (1996) have identified the ambiguous, sometimes indefinite referencing possibility of spatial deictics. Using the example of a message recorded into an answering machine, Yule (1996:12) convincingly submits that technology can allow the speaker to be meaningful in the seemingly incongruous utterance:

\section{I'm not here now.}

By means of what he calls, "dramatic performance to a future audience", thus projecting his/her presence in the required location. As such, meaning-making in the use of spatial deictics is both a physical and cognitive exercise. Temporal indexicals concern the "when" of the utterance. The time of an utterance is reflected by the verb-tense (past present future) and adverbs of time (e.g then, now). And so, deixis is divisible into three temporal categories of "past" (before the moment of utterance), "present" (at the moment of utterance) and "future" (after the moment of utterance). However, this neat, tristratal demarcation is more complex than it seems. Since it is at the moment of the utterance that we encounter it, temporal deictics are usually balanced against, and interpreted as, "present tensed locutions" (Smith, 1989) .Smith (1989:5-9) applying this principle, has identified historical time, future time and imaginary time. The historical time is the speaker's chronological point of reference, as in:

It is January 20, 2009, Barrack

Obama is being sworn in as the president of America.

The future time refers to the time of the event, as in the tape- recording of the 
announcement of future event, on a preceding day:

$$
\begin{aligned}
& \text { Yes, today is January 1, } 2006, \\
& \text { you are welcome to this } \\
& \text { programme. }
\end{aligned}
$$

The imaginary time of the events, especially through the flashback literary technique, where the past is given a presentness.

From the foregoing, deictics are used for referential purposes in salient and relevant contexts. Garcia-Murga (1995:5) elaborates, the "Reference of indexicals shifts with utterances, depending on the current user, and their referents are partly determined by extralinguistic context."

\section{METHOD}

This article use qualitative research by analyzing the deixis. Here, the writer analyzes the use of deixis. The speech of Obama is taken as the source of data. The procedures of data collection include listing and grouping the deixis. Then the collected data are analyzed one by one. The speech includes two.

\section{RESULTS AND DISCUSSION Inclusive Deixis in Text A}

Studies in political language have investigated politicians' use of deictics for various purposes, ranging from personal to political, from persuasive to manipulative, all essentially dependent on both the context of production and the speaker's intentions. Kuo (2001, 2002), and Wilson (1990) have explored the use of deixis for indexing political debates. Kuo (2001) and Kuo (2002), two sides of a coin, are situated in the televised debates of the 1998 Taipei mayoral elections: the one, an analysis of the candidate's use of direct quotation for both self-promotion and the validation of opponents, the other an illustration of the deployment of the second person plural, pronoun "ni" (you) by the three mayoral candidates for establishing solidarity with the audience or attacking opponents. Both of Kuo's studies reflect how deictics are put to referentiatial, impersonal and other sundary uses for effecting linguistic interaction in political discourse. Wilson (1990) interprets the shifting status of "I" and "we", as deployed by Geraid ford and Jimmy Carter, both participants in the United States presidential debates of 1976 . He anchors a politician's shift of reference on self-positioning the desire to spread the load of responsibility, and the fear of being misinterpreted, by the audience or co-debater. Inigo-Mora (2004) studies the strategic use of the first person plural pronoun "we" for enacting personal identity and deictic five "Question Time sessions" of House of Commons (British Parliament), held between December, 1987 and April, 1988, she locates four distinctive types of "we" exclusive, generic and parliamentary a variation manipulated by the politician for engendering "approaching-distancing relationship" (p 49).

Lwaitama (1988), Maitland and Wilson (1987) and Urban (1986) have investigated the deictic content of public oratory. Lwaitama (1988), analysing the employment of "I" and "we" by Nyerere and Mwinyi (both former presidents of Tanzania), sights variations, occasioned by context and person. Differentiating between the scripted and unscripted speeches of both politicians, especially as they contain the various forms of "we", he posts that Nyerere used more exclusive, while Mwinyi used more inclusive forms in scripted than unscripted speeches, a distinction, he suggests, is, occasioned by both speakers' Kiswahili-speaking statues (Kiswahili is Mwinyi first 
language while it is Nyerere's second). Maitland and Wilson (I1987) analyse the deployment of personal pronouns in the speeches of three British politicians Foot, Kinnock, and Thatcher_for the purposes of "self -referencing", "relations of contrast" and "other referencing". They discover obvious similarities, in the use of these deictics, between Kinnock and Foot (both members of the labour party) and differences between Foot/Kinnock and Thatcher (a member of the Conservative Party). Urban (1986) delves into the deployment of the first person pronouns as variably distributed in selected speeches of Casper Weinberger, (former United States Defense Secretary). Focusing on the plural pronouns, he selects six forms of "we", as illustrations of how the speaker tries to persuade his audience to overcome the problems in the country.

No work, none that this researcher is aware of has studied the deictic status of American political discourse. This work thus hopes to fill this gap and thereby direct the focus of pragmaticians towards the rich research potentials of American political language

Let us now dissect Obama's speeches with the identified indexicals, first as inclusive, then as exclusive, markers, respectively.

\section{Inclusive Deixis in Text A}

Text $A$ is a transcribed text of a presidential speech made at Greenhouse when inaugural address. The speaker is Barack Obama and his audience includes American, other American, and non-American. The three kinds of personal deictics are put to good use. The first person pronouns, in their singular and plural forms, are used intermittently to convey their traditional singular and plural notions. The subjective "I" is used $2^{\text {nd }}$ times, its objective and possessive forms two times each, all referring to the speaker as the the citizen, and as the future president of the American government. This is captured in the following extracts:

A1: I stand here today humbled by the task before us, grateful for the trust you have bestowed, mindful to the sacrifices borne by our ancestors.

A2: I thank president Bush for his service...

A3: Today I say to you that the challenges we face are real.

The few singular indexicals however give way to the plural forms too soon.

The deictics "we" and its variants "our" and "us" are deployed in myriad ways. There is a high incidence of these pronominal deictics ("we" is used fifty times, "our", eighteen times, "us", fourteen times) even though their referents are often not definite. However what is incontrovertible is the speaker-inclusive reference of this plural pronominal. It is the "we" (Wilson, 1990; Miller 2004), which refers to the executive arm of the Obasanjo-led Nigerian government that has the highest incidence. This is evidenced by the extracts below:

A4: We remain the most prosperous, powerful nation on earth. Our workers are no less productive than when this crisis began. Our minds are no less inventive.

Also, the speaker feels confident that he can overcome the problem in his country. This is illustrated below:

A5: we are keepers of this legacy. Guided by these principle once more, we can meet those new threats....

A6: We know that our patchwork heritage ia a strength, not a 
weakness. We are a nation of cristians and muslims, Jews and Hindus-....

There are examples of the use of the second person pronominal deictic "you", all referring to the audience. This situation is represented below.

A7: We pledge to work along side you to make your farms flourish ...

The third person plural pronoun is also an ubiquitous deictic in the text realised as "they", them, and "their", these deictics are used to the challenge or problem in America.

A7: I say to you that the challenge we face are real. They are serious and they are many....

Temporal adverbials are also used in this text to situate the speech in its proper historical context. For a speech delivered in 2009, in the year of American's birth as in this sentence in the year of America's birth, in the oldest of months....

The spatial deictics we encounter are few. They are basically "this". "This" occurring three times refers variously to the topic of discussion, "price and the promise of citizenship", "the source of our confidence", meaning of liberty.

A8: This is the price and the promise of citizenship.

A9: This is the source of our confidence......

A10: This is the meaning of our liberty....

Thus far, we have been able to locate deixis in text A. Though, the indexicals have been used to different levels of intensity, they all situate the speaker in a collaborative communication with the audience. The speaker's positioning regarding the context and form of the discourse, is thus self-inclusive and audience inclusive. As such the macro- textual interpretation of deictic use in Text A is "inclusion".

\section{Deixis as Exclusive in Text $B$}

The deictic situation in text $\mathrm{B}$ is unlike what obtains in text A the textual forms and contents of the two speeches are different. Text B is shout out of Obama about library. A president who proud to the education and aware to the economy.

The most recurrent deictic is the first person singular pronoun "I". This is understandable as the speaker is here giving personal opinions about the importance of library. Library is used as holy place for studying. This is illustrated below:

B1: so, I'm here to gratefully acknowledge the importance of libraries and the work you do.

B2: I also want to work with you to insure...

Beyond this description of personal efforts, the speaker's use of "I" confers gratefully (Chilton and Schaffner, 1997: 216) legitimization on the speaker's action.

B3: I know some of you here have been subject to FBI or other.....

B4: I hope we can pass.....

The first person singular subjective and possessive pronouns, variants of "I", "me" and "my" also refer undoubtedly to the speaker, in the two capacities of a person and a president. The allinclusive "we" has been deployed by the speaker to bring on to his side, the audience, in his ideological and power positioning. "We", and its variants, "our", "ours" and "us", therefore represent, what Adegoju (2005:140) defines as, "the coalescence of the voice of the person with the voice of the people". Let us see two cases:

B5: We protect our most cherished....

B6: We have to change our whole.... 
The third person plural pronoun, "they" and its allied forms, "them", "themselves" are used in Text B to refer to two major sets of people:

B7: before they can ever fill.....

\section{CONCLUSION}

Thus far, we have been investigating the functions of deixis in political discourse, from the perspective of two of Obasanjo's speeches. Findings reveal that two speeches, even by the same speaker are scarcely similar. In text $\mathrm{A}$, the deictic centre is nearer the plural "we" than the usual, singular "I". This reflects the allembracing content and context of the speech, which is given away by the rapport-inviting opening sequence, "Distinguished Ladies and Gentlemen". As such "we", the commonest personal deictic in the speech, has been deliberately employed by the speaker to convince and probably manipulate the audience to reason like him and help him in sharing the load of responsibility. In text B, the deictic "I" preponderates, essentially because the speaker speaks from a personal point of view, verbalising a particular conviction which general.

The temporal sequence of the deictic configuration in texts $\mathrm{A}$ and $\mathrm{B}$ are similar, "we" encounters a plethora of adverbial time markers which situate the actions, positions, and situations being described in their proper time frames. The tenses are cast in present and past modes while modal auxiliaries are used to exemplify future references. In text $\mathrm{B}$, the speaker gives the history of the action he is about to take, especially the importance of library for social of the country. This is probably due to the fact that political discourse is basically interactive and dialogic. Spatial indexicals are most frequently used however for self-exclusive purposes, as represented by the singular and the plural pronominal.

\section{REFERENCES}

Ayodabo, J. O. (2003). A PragmaStylistic Study of Abiola's Historic Speech of June 24, 1993. In Lawal, A. (ed) Stylistics in Theory and Practice. Ilorin: Paragon Books.

Braun, D. (2001). Indexicals. Stanford Encyclopaedia of Philosophy.

Cap, P. (2002). Explorations in Political Discourse: Methodological and Critical Perspectives. Frankfurt am Main: Peter Lang Verlag.

Chilton, P. (2004). Analysing Political Discourse. London: Routledge.

Chilton, P., \& Schaffner, C. (1997). Discourse Pragmatics in van Dijk, $\mathrm{T}$ (ed) Discourse as Social Interaction. London: Sage.

Garcia- Murga, F. (1995). Indexicals and descriptions. SORITES, 2, 4656.

Geis, M. (1987). The Language of Politics. New York: Springer Verlag.

Goffman, E. (1981). Forms of Talk. Oxford: Blackwell.

Inigo-Mora, I. (2004). On the use of the personal pronoun we in communities. Journal of Language and Politics, 3(1), 2752.

Kataoka, K. (2004). Co-construction of a mental map in spatial discourse: A case study of Japanese rock climbers' use of deictic verbs of motion. Pragmatics, 14(4), 409438.

Kuo, S. (2001). Reported speech in Chinese political discourse. Discourse and Society, 3(2), 8181-2002.190

(2002). From solidarity to antagonism: the uses of the 
second person singular pronoun in Chinese political discourse. Text, 22(1), 29-55.

Levinson, S. (1983). Pragmatics. Cambridge: Cambridge University Press.

Lwaitama, A. F. (1988). Variations in the use of personal pronouns in the public oratory of J.K Nyerere and A.H Mwinyi. Belfast Working Papers in Language and Linguistics, 1, 1-23.

Maitland, K. (1988). Why Choose Me: The Pragmatics of English Pronouns. D Phil Dissertation, University of Ulster.

Maitland, K., \& Wilson, J. (1987). Pronominal selection and ideological conflict. Journal of Pragmatics, 11(4), 495-512.

Mey. (2000). When Voices Clash: A study in Literary Pragmatics. New York: Mouton de Gruyter.

Mey, J. (2001). Pragmatics: An Introduction (2nd Edition). Oxford: Blackwell.

Odebunmi, A (2001): The English Word and Meaning: An Introductory Text. Ogbomoso: Critical Sphere.

Odebunmi, A., \& Olaniyan, K. (2005). Perspectivization in Fiction: A Deictic Study of Wole Soyinka's Ake (Mimeo).

Oha, O. (1994). Language in War Situation: A Stylistic Study of the War Speeches of Yakubu Gowon and Emeka Ojukwu. Ph.D Dissertation, University of Ibadan, Ibadan.
Rees, A. (1983). Pronouns of Person and Power: A Study of Personal Pronouns in Public Discourse. M.A Dissertation, University of Sheffield.

Rudd, P. W. (2004). Weapons of mass destruction: the unshared referents of Bush's rhetoric. Pragmatics, 4(4), 499-525.

Thomas, J. (1995). Meaning in Interaction: An Introduction to Pragmatics. London: Longman.

Trask, R. L. (1999). Key Concepts in Language and Linguistics. London: Routledge.

Urban, G. (1986). Rhetoric of a War Chief. Working Papers and Proceedings of the Centre for Psychological Studies, 5, 1-27.

Van Dijk, T. (2004). Political discourse and racism: describing others in western parliaments in Riggins, S. $\mathrm{H}$. (ed) The Language and Politics of Exclusion. London: Sage. . (2004). Politics, Ideology and Discourse. Encyclopedia of Language and Linguistics in Wodak, R. (ed) Language and Politics.

Volosinov, V. N. (1973). Marxism and the Philosophy of Language. New York: Seminar Press.

Wilson, J. (1990). Politically Speaking: The Pragmatic Analysis of Political Language Oxford: Blackwell.

Yule, G. (1996). Pragmatics. Oxford: Oxford University Press. 